\title{
FROM THE PROFESSION
}

CLIO: An Interdisciplinary Journal of Literature, History, and the Philosophy of History is expanding for the Fall of 1977 to offer an equal concentration on philosophy of history, especially the thought of Hegel. Clark Butler is joining Robert H. Canary and Henry Kozicki as new coeditor, and J. N. Findlay, H. S. Harris, and Otto Pöggeler as new Advisory Editors. Articles and reviews are invited for these regions, as well as for CLIO's usual offerings in history-related literary criticism and literary analyses of history writing. Subscriptions remain the same: $\$ 6$ for individuals and $\$ 15$ for institutions. All correspondence to CLIO, Indiana University-Purdue University, Fort Wayne, Indiana 46805. 